\title{
Effects of the dexamethasone intravitreal implant (Ozurdex intraocular pressure for the treatment of macular edema
}

\section{Efectos del implante intravítreo de dexametasona $\left(\mathrm{Ozurdex}^{\circledR}\right)$ en la presión intraocular para el tratamiento del edema macular}

\author{
Sergio Arrascue ${ }^{1}$, Johana Rueda ${ }^{2}$, Juan Unigarro ${ }^{1}$, Sofía Vidal', Linda Espinosa ${ }^{2}$, Jorge Acosta-Reyes ${ }^{3}$ \\ and Carlos Abdala-Caballero ${ }^{4 *}$
}

${ }^{1}$ Retina and Vitreous Department, Clínica Unidad Láser del Atlántico; ${ }^{2}$ Department of Ophthalmology, Universidad del Norte; ${ }^{3}$ Department of Public Health, Universidad del Norte; ${ }^{4}$ Retina and Vitreous Department, Clínica Unidad Láser del Atlántico. Barranquilla, Colombia

\begin{abstract}
Purpose: To analyze the effects on intraocular pressure (IOP) of the sustained-release dexamethasone implant (Ozurdex ${ }^{\circledR}$, Allergan Inc., Irvine, CA, USA) for the treatment of macular edema. Methods: Retrospective study of patients receiving at least one dose of the sustained-release dexamethasone implant between January 2012 and June 2016 in the private retinal practice of a referral center in Barranquilla, Colombia. Ocular hypertension was defined as an $I O P \geq 21 \mathrm{mmHg}$ or an increase of at least $10 \mathrm{mmHg}$ from baseline. The monthly change in IOP during 6 months of follow-up and the relationship with a previous diagnosis of glaucoma was evaluated. Results: Thirty-seven cases were reviewed, with an initial IOP between 9 and $22 \mathrm{mmHg}$. Hypertension during the 6 months of follow up with topical antihypertensive requirement was observed in 21 cases (56.7\%). In 11 cases (29.7\%) IOP increased to $\geq 21 \mathrm{mmHg}$, in $6(16.2 \%)$ it increased $\geq 25 \mathrm{mmHg}$ and, in four cases to $\geq 10 \mathrm{mmHg}(10.8 \%)$ above the baseline IOP after the $1^{\text {st }}$ month. Likewise, after the $1^{\text {st }}$ month there was an average variation of $3.8 \pm 6 \mathrm{mmHg}(p=0.001)$ and of $1.67 \pm 5.6 \mathrm{mmHg}(p=0.002)$ after the $2^{\text {nd }}$ month. There were no statistical differences in patients with and without previous glaucoma. The highest increase in IOP at the first month was observed in cases with edema due to central serous chorioretinopathy (CSC) and Vogt-Koyanagi-Harada (VKH), with a mean of 23 and $21 \mathrm{mmHg}$ respectively; however, this was not statistically significant. Conclusion: A large percentage of patients receiving Ozurdex ${ }^{\circledR}$ have ocular hypertension (56.7\%), requiring management with topical antihypertensive drugs, independently of the history of glaucoma and the etiology of the edema. The highest increase occurred at the $1^{\text {st }}$ month of treatment, remaining at the $2^{\text {nd }}$ and $4^{\text {th }}$ months, with a lower significance in the $6^{\text {th }}$ month after treatment.
\end{abstract}

Key words: Intraocular pressure. Ocular hypertension. Glaucoma. Dexamethasone implant.

\section{Resumen}

Propósito: Analizar los efectos en la presión intraocular (PIO) del implante de liberación sostenida de dexametasona (Ozurdex ${ }^{\oplus}$, Allergan Inc., Irvine, CA, USA) para el tratamiento del edema macular. Métodos: Estudio retrospectivo de pacientes que recibieron al menos una dosis de implante de liberación sostenida de dexametasona desde enero de 2012 a junio de 2016 en la práctica privada de retina de un centro de referencia de Barranquilla, Colombia. La hipertensión ocular se definió

Correspondence:

${ }^{*}$ Carlos Abdala-Caballero

Carrera 52 N84-98 Cons. $205 \quad$ Date of reception: 18-09-2017

Barranquilla, Colombia Date of acceptance: 01-06-2018

E-mail: cabdala@unidadlaserdelatlantico.com DOI: 10.24875/RMOE.M18000031

2604-1731/O 2018 Sociedad Mexicana de Oftalmología. Published by Permanyer México SA de CV. This is an Open Access article under the CC BY-NC-ND license (http://creativecommons.org/licenses/by-nc-nd/4.0/). 
como una $P I O \geq 21 \mathrm{mmHg}$ o un incremento de al menos $10 \mathrm{mmHg}$ de su valor base. Se evaluó el cambio en la PIO mensual durante 6 meses de seguimiento y la relación con el diagnóstico previo de glaucoma. Resultados: Se revisaron 37 casos, con PIO inicial entre 9 y $22 \mathrm{mmHg}$. Se presentó hipertensión durante los 6 meses de seguimiento con requerimiento antihipertensivo tópico en 21 casos (56.7\%). En 11 casos (29.7\%) aumentó la PIO a $\geq 21 \mathrm{mmHg}$, en 6 (16.2\%) aumentó a $\geq 25 \mathrm{mmHg}$ y en 4 aumentó $\geq 10 \mathrm{mmHg}(10.8 \%)$ por encima de la PIO basal después del primer mes. Así mismo, después del primer mes se presentó una variación promedio de $3.8 \pm 6 \mathrm{mmHg}(p=0.001)$ y al segundo mes de $1.67 \pm 5.6 \mathrm{mmHg}$ $(p=0.002)$. No hubo diferencias estadísticas en los pacientes con y sin glaucoma previo. El mayor aumento de la PIO al primer mes se encontró en los casos con edema por coriorretinopatía serosa central crónica y por enfermedad de Vogt-Koyanagi-Harada, con un promedio de 23 y $21 \mathrm{mmHg}$, respectivamente; sin embargo, no tuvieron significancia estadística. Conclusión: Un amplio porcentaje de pacientes que reciben Ozurdex ${ }^{\oplus}$ presentan hipertensión ocular (56.7\%), que requiere manejo con antihipertensivos oculares tópicos, independientemente del antecedente de glaucoma y de la etiología del edema. El mayor aumento se presentó al primer mes de tratamiento, y se mantuvo durante el segundo y cuarto mes, con una menor significancia hacia el sexto mes después del tratamiento.

Palabras clave: Presión intraocular. Hipertensión ocular. Glaucoma. Implante de dexametasona.

\section{Introduction}

Corticosteroids have been an important therapy in retinal diseases for decades due to their role in the prevention of leukocyte migration, stabilization of endothelial tight junctions and inhibition of vascular endothelial growth factor, prostaglandins and cytokines. The routes of administration are varied, since they can be administered orally, intravenously, topically, periocular and intravitreal ${ }^{1,2}$.

One of the side effects of corticosteroid treatment is ocular hypertension that may occur after any route of administration. The mechanism that contributes to the elevation of intraocular pressure (IOP) is complex. In this mechanism, the modification or blocking of the ultrastructure of the trabecular meshwork is involved, through the inhibition of proteases and phagocytosis of the trabecular cells, which increases the resistance to aqueous humor drainage, generating a reduction in filtration, and thus, increasing $\mathrm{IOP}^{3}$.

Ozurdex® (DEX implant $0.7 \mathrm{mg}$, Ozurdex, Allergan Inc., Irvine, CA, USA) is a biodegradable slow-release dexamethasone implant that provides $700 \mu \mathrm{g}$ of preservative-free dexamethasone. It is made of a solid biodegradable polymer that allows a dual pharmacokinetics, an acute phase of dexamethasone release that quickly reaches a therapeutic concentration, followed by a more sustained release. The Food and Drug Administration (FDA) has approved its use in the treatment of macular edema (ME) associated with retinal vein occlusion, diabetic ME and non-infectious uveitis ${ }^{1,2}$.

The dexamethasone implant has a side-effect profile to consider, mainly the progression of cataracts and ocular hypertension. Retinal detachment and endophthalmitis have also been reported as rare complications ${ }^{1,2}$.

\section{Objective}

To analyze the effects of the Ozurdex® implant on IOP in a cohort of patients treated for ME from different etiologies in a private retina and vitreous practice of a reference center in Barranquilla, Colombia, including patients with history of glaucoma and adequate IOP control. Also, to analyze IOP variation during a 6 -month follow-up period.

\section{Methods}

Descriptive retrospective study in which the records of the private retinal and vitreous consultation database of the Clínica Unidad Láser del Atlántico in BarranquiIla, Colombia, were evaluated from January 2012 to June 2016. We analyzed the cases of patients with clinical and imaging diagnosis of $\mathrm{ME}$, who received at least one dose of Ozurdex®, with a follow-up period of at least 6 months.

\section{Inclusion and exclusion criteria}

The following variables were recorded: age, sex, treated eye, associated comorbidities, type of ME, history of glaucoma or ocular hypertension controlled with ocular antihypertensive monotherapy. IOP was measured before the first dose and from month 1 to 6 after the placement.

Ocular hypertension was defined as an IOP of at least $21 \mathrm{mmHg}$ or an increase of at least $10 \mathrm{mmHg}$ from baseline, according to the definition of ocular hypertension of the American Academy of Ophthalmology.

The change in monthly IOP from month 1 to month 6 of follow-up was analyzed; these data were compared 
Table 1. Shows the characteristics of the studied population, the pathologies associated with the use of intravitreal Ozurdex® and the need of topical antihypertensive therapy.

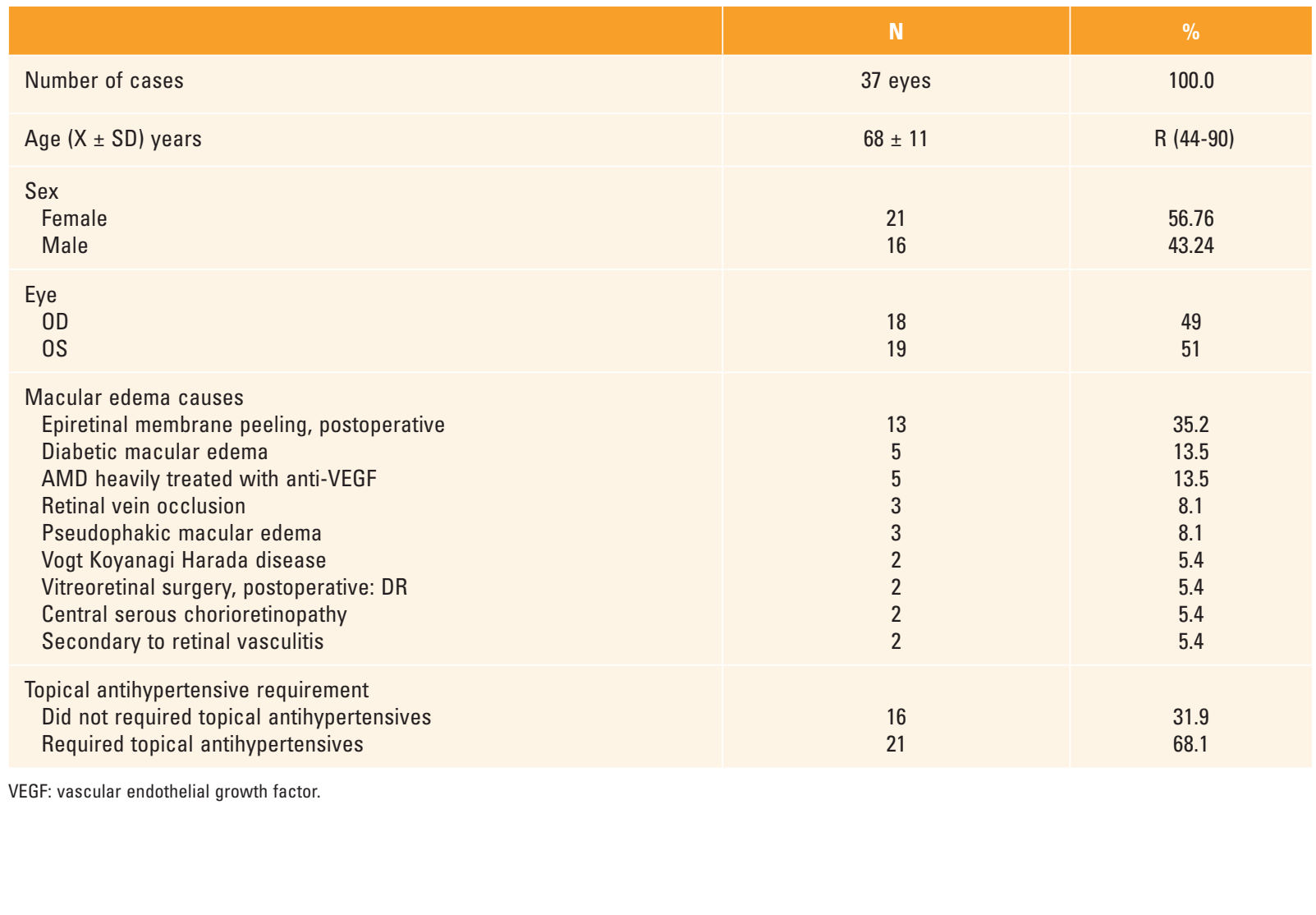

to the initial IOP values, as well as the relationship between IOP and the type of ME.

Qualitative variables were studied with percentages, frequencies, and quantitative variables with means and standard deviations. Data were analyzed with the SPSSv20 software.

\section{Results}

We reviewed 68 medical records, of which 40 had a diagnosis of ME treated with at least one dose of Ozurdex®. Three cases were excluded due to absent IOP values during follow-up. Thirty-seven eyes were included in the study.

The age range was 44 to 90 years (mean \pm SD, $68 \pm 11$ ), of which 21 eyes (56.76\%) corresponded to female patients and $16(43.24 \%)$ to male, with the same percentage of right and left eyes. The main comorbidity observed was arterial hypertension $(41.2 \%)$, followed by diabetes mellitus $(20.2 \%)$, hypothyroidism $(12 \%)$, heart disease $(8.6 \%)$ and others (18\%). All the cases were pseudophakic. Among the indications for Ozurdex® were postoperative ME due to epiretinal membrane peeling in 13 cases $(35.2 \%)$, diabetic ME
(13.5\%), heavily treated wet age-related macular degeneration (AMD) (13.5\%), ME secondary to central retinal vein occlusion (CRVO) and pseudophakic ME (8.1\% each), ME secondary to retinal vasculitis, chronic central serous chorioretinopathy (CSC), Vogt-Koyanagi-Harada disease $(\mathrm{VKH})$ and postoperative retinal detachment, that occurred in only two cases each (5.4\% each) (Table 1$)$.

The initial IOP ranged from 9 to $22 \mathrm{mmHg}$ (mean \pm $\mathrm{SD}, 14 \pm 2.8$ ). At month 1 , an average of $18 \pm 5.4 \mathrm{mmHg}$ was found, at month 2, $16 \pm 4 \mathrm{mmHg}$ and at month 6 , $15 \pm 3 \mathrm{mmHg}$ (Fig. 1). Of the eyes managed with Ozur$\operatorname{dex} 囚, 21(56.7 \%)$ required ocular antihypertensive therapy at some point during the 6-month follow-up. In 11 cases $(29.7 \%)$, the IOP was $\geq 21 \mathrm{mmHg}$, in six cases (16.2\%), the pressure increased to values $\geq 25 \mathrm{mmHg}$, and in 4 cases, there was an increase of $\geq 10 \mathrm{mmHg}$ $(10.8 \%)$ from baseline IOP after the first month of treatment. At month 1 of treatment, IOP values showed an average variation of $3.8 \pm 6 \mathrm{mmHg}(p=0.001,95 \%$ $\mathrm{Cl}:-5.9$ to -1.8$)$, ranging from 10 to $28 \mathrm{mmHg}(18 \pm$ $5.4 \mathrm{mmHg}$ ); at month 2, the mean variation was $1.67 \pm$ $5.6 \mathrm{mmHg}(p=0.002,95 \% \mathrm{Cl}:-3.1$ to -0.25$)$, and 6 months after the Ozurdex® implant, IOP variation 


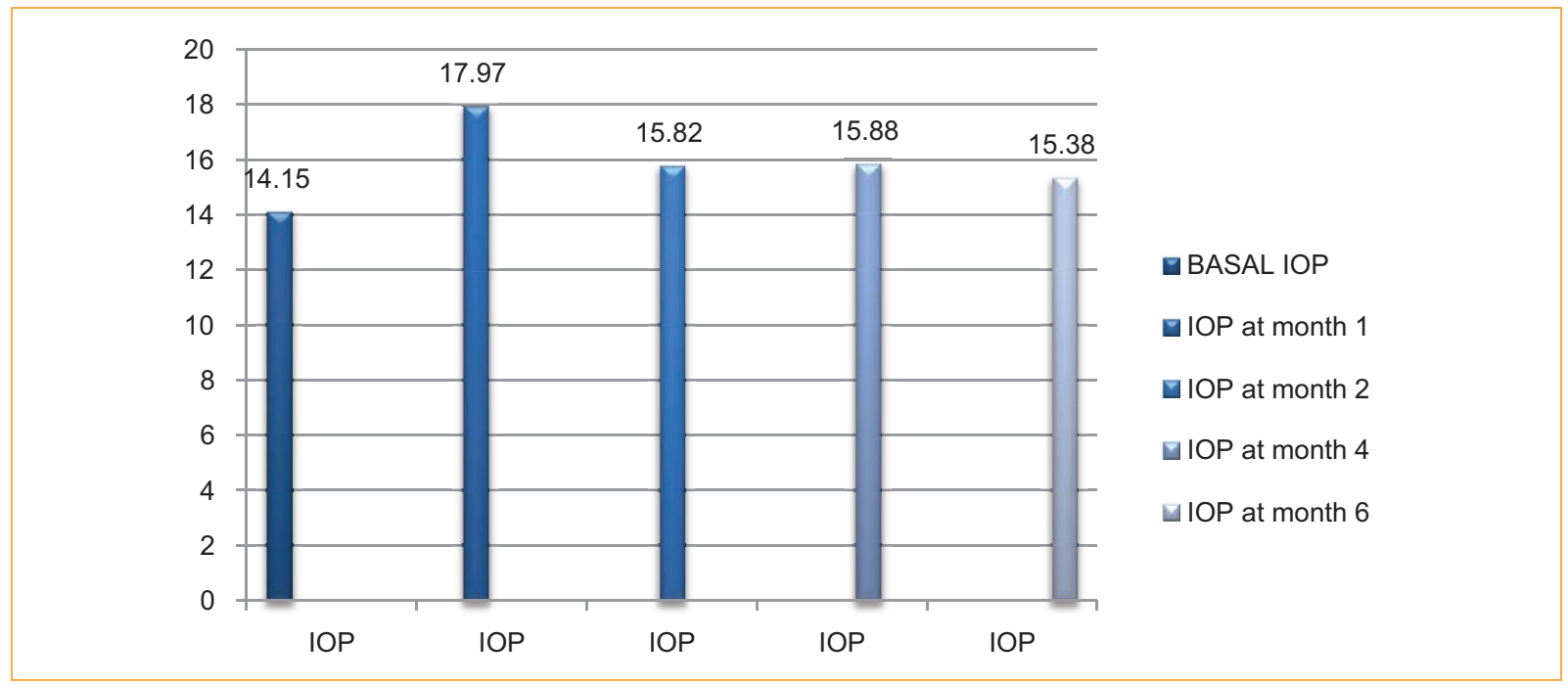

Figure 1. IOP variation at months 1, 2, 3 and 6 in the studied population.

Table 2. Shows the IOP variation at months 1, 2 and 6 in the overall population and the difference compared to the average initial IOP.

\begin{tabular}{|l|c|c|c|}
\hline IOP (mmHg) & All & Difference with initial IOP & P value - Cl \\
\hline No. of eyes & 37 & & $100 \%$ \\
\hline Initial IOP & 14.5 & 0 & \\
\hline IOP 1 month & 17.97 & $3.8 \pm 6 \mathrm{mmHg}$ & $\mathrm{p}=0.001 ; 95 \% \mathrm{Cl}:-5.9$ to -1.8 \\
\hline IOP 2 months & 15.82 & $1.67 \pm 5.6 \mathrm{mmHg}$ & $\mathrm{p}=0.002 ; 95 \% \mathrm{Cl}:-3.1$ to -0.25 \\
\hline IOP 6 months & 15.38 & $1.23 \pm 3.7 \mathrm{mmHg}$ & $\mathrm{p}=0.63 ; 95 \% \mathrm{Cl}:-2.54$ to 0.1 \\
\hline
\end{tabular}

IOP: intraocular pressure.

compared to the initial values was $1.23 \pm 3.7 \mathrm{mmHg}$ ( $p=0.63,95 \% \mathrm{Cl}-2.54$ to 0.1 ) (Table 2).

Of the patients treated, six (16.2\%) had a history of glaucoma prior to the initiation of treatment and were receiving ocular antihypertensive therapy, both combined and as monotherapy (timolol $5 \mathrm{mg} / \mathrm{ml}$ and dorzolamide/timolol $20 \mathrm{mg} / \mathrm{ml} / 5 \mathrm{mg} / \mathrm{ml}$ ). The average initial IOP in patients with glaucoma was $15 \mathrm{mmHg}$ and in patients without previous glaucoma, $14 \mathrm{mmHg}$. In patients with previous glaucoma, a greater increase in IOP was found in the first, third and sixth months, with a variation of $2.6 \mathrm{mmHg}(p=0.252,95 \% \mathrm{Cl}: 7.96-2.62), 1.6 \mathrm{mmHg}$ $(p=0.459,95 \% \mathrm{Cl}: 7.0-3.67)$ and $1.8 \mathrm{mmHg}(\mathrm{p}=0.177$, 95\% Cl: 4.83-1.16), respectively, and it was higher in patients without glaucoma, in whom a greater increase was found during the first month, with an average of $4 \mathrm{mmHg}(\mathrm{p}=0.002,95 \% \mathrm{Cl}: 6.44-1.7)$, an average variation of $1.7 \mathrm{mmHg}$ from the second month that persists until the fifth month $(p=0.33,95 \% \mathrm{Cl}: 3.2-0,149)$ and of $1 \mathrm{mmHg}$ at month 6 ( $\mathrm{p}=1.49,95 \% \mathrm{Cl}$ : 2.6-0.42) (Fig. 2). Only one case with glaucoma history showed an IOP increase of $\geq 10 \mathrm{mmHg}$ from baseline, which occurred one month after treatment. We also found four cases at month 1 , one case at month 3 , two cases at month 4 and one case at month 5 , in which IOP increased $\geq 10 \mathrm{mmHg}$ from baseline after treatment.

Regarding the type of edema, there were no statistically significant differences in the initial IOP values. The greatest increase in IOP at the first month was observed in cases with edema due to CSC and VKH, with an average of 23 and $21 \mathrm{mmHg}$, respectively; however, this was not statistically significant.

\section{Discussion}

In our study, we found an incidence of ocular hypertension (IOP values $\geq 21 \mathrm{mmHg}$ or IOP elevation $\geq$ $10 \mathrm{mmHg}$ from baseline IOP) ${ }^{4}$ after Ozurdex ${ }^{\circledR}$ 


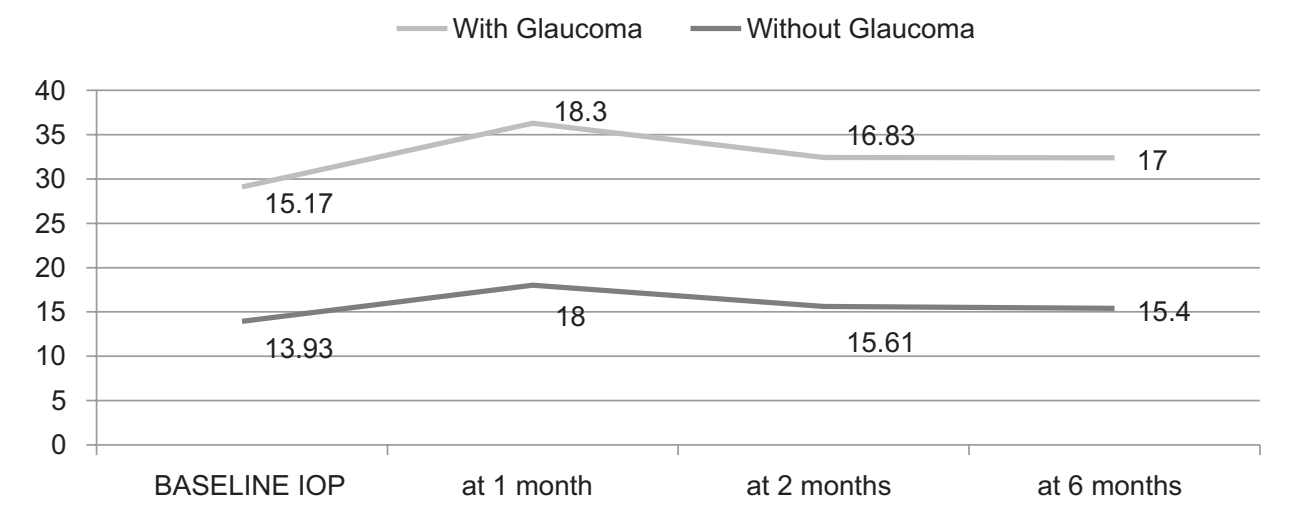

Figure 2. IOP variation at months 1, 2, 3 and 6 in the population with and without glaucoma history.

treatment of $56.7 \%$, similar to that reported by Maturi, et al., who reported an incidence of $41.5 \%{ }^{5}$, and well above compared to that reported by Mazzarella, et al. and Chin et al., as well as Haller, et al., who observed that $32.6 \%, 26.9 \%$ and $24 \%$ of the patients, respectively, presented ocular hypertension ${ }^{6-8}$.

Our study shows that $16.2 \%$ of the treated patients had an IOP $\geq 25 \mathrm{mmHg}$, very similar to the values reported in the GENEVA study, one of the main studies on the use of Ozurdex®, which showed an incidence of $16 \%$ for these cases. Likewise, our results differ from those reported by Huron, et al., where $<10 \%$ also presented these IOP values, differing from that reported by Malcles, et al. in one of the studies with the highest number of cases reported, where they report an incidence of $31 \%$ of cases with IOP $\geq 25 \mathrm{mmHg}$ that required topical ocular antihypertensive agents ${ }^{8-10}$. The IOP increase $\geq 10 \mathrm{mmHg}$ observed in our study was of $10.8 \%$, similar to that found by Schmitz, et al. (9\%) and well below that reported by Maturi, et al. (27.7\%), as well as by Meyer, et al. (50\%) and Maicles, et al. (27\%), which is why we believe that it is necessary to perform a study with a greater number of cases in a population like ours ${ }^{5,11-13}$.

The maximum peak in most reports was observed at 2 months, with a regression to baseline values around 6 months $\mathrm{s}^{5,8,14}$. We observed a higher IOP elevation after the first month of treatment with Ozurdex®, with values of $18 \pm 5.4$, which varied slightly in the second month (16 \pm 4 ), and similarly returned to baseline values on month six, agreeing with the data reported by Chin, et al.?.

In our study, no statistically significant difference was found between the final IOP measurements of patients with and without history of glaucoma, similar to that reported by Schmitz, et al., as well as by Jiménez, et al. ${ }^{13,14}$. This differs with that reported by Mazzarela et al., who found an incidence of ocular hypertension of $21.5 \%$ in their non-glaucomatous population versus $59.3 \%$ in their glaucomatous population ${ }^{6}$. Our study showed that the non-glaucomatous population had higher IOP peaks after treatment with Ozurdex®, which could be associated with the greater population that represents our non-glaucomatous group. Thus, we recommend prospective studies with a greater number of cases in both populations.

Regarding the type of edema, the edema associated with RVO and uveitis, correlated better with an increase in ocular hypertension in patients treated with Ozur$\operatorname{dex} \circledast$ than the diabetic and postoperative edema.

\section{Conclusion}

A large percentage of patients receiving Ozurdex $®$ presented ocular hypertension, $56.7 \%$ in our study, which required management with topical ocular antihypertensives, with a good response to treatment and few adverse outcomes, regardless of the history of glaucoma and the etiology of the edema. In our study, the highest increase in IOP occurred at the first month of treatment and persisted in the second and fourth months, with a significant decrease towards the sixth month after treatment.

We consider important to monitor the IOP of patients who receive treatment with Ozurdex $®$ during the first 4 months after treatment, as well as the use of topical ocular antihypertensive agents for its management. 
It is important to consider the limitations of our study, such as its retrospective nature, the number of patients and the limited follow-up period.

We recommend carrying out prospective, multicenter studies with a greater number of cases in our population.

\section{Ethical disclosures}

Protection of human and animal subjects. The authors declare that no experiments were performed on humans or animals for this study.

Confidentiality of data. The authors declare that they have followed the protocols of their work center on the publication of patient data.

Right to privacy and informed consent. The authors declare that no patient data appear in this article.

\section{References}

1. London N, Chiang A, Haller J. The dexamethasone drug delivery system: indications and evidence. Adv Ther. 2011;28(5):336-51.

2. Kapoor K, Wagner M, Wagner A. The sustained release dexamethasone implant: expanding indications in viteoretinal disease. Semin Ophthalmol. 2015;30(30):5-6.
3. Mansour F. Effect of Corticosteroids Fluid Dynamics. Arch Ophthalmol. 1963;70:482-91

4. Ophthalmology AA of. Glaucoma. In: Basic and Clinical Science Course. p. 33-50.

5. Maturi RK, Pollack A, Uy HS, Varano M, Gomes AM V., Li X-Y, et al. Intraocular Pressure in Patients With Diabetic Macular Edema Treated With Dexamethasone Intravitreal Implant in the 3-Year Mead Study. Retina. 2016;1.

6. Mazzarella S, Mateo C, Freixes S, Burés-Jelstrup A, Rios J, Navarro R, et al. Effect of Intravitreal Injection of Dexamethasone $0.7 \mathrm{mg}$ (Ozurdex®) on Intraocular Pressure in Patients with Macular Edema. Ophthalmic Res. 2015;54(3):143-9.

7. Chin E, Almeida D, Velez G, Xu K, Peraire M, Corbella M, ef al. Ocular Hypertension After Intravitreal Dexamethasone (Ozurdex) Sustained-Release Implant. Retina. 2016;0(0):1-7.

8. Haller JA, Bandello F, Belfort R, Blumenkranz MS, Gillies M, HeierJ, et al. Randomized, Sham-Controlled Trial of Dexamethasone Intravitreal Implant in Patients with Macular Edema Due to Retinal Vein Occlusion. Ophthalmology. 2010;117(6):1134-1146.e3.

9. Malclès A, Dot C, Voirin N, Vié A, Agard É, Bellocq D, et al. Safety of Intravitreal Dexamethasone Implant (Ozurdex). Retina. 2017:37(7): 1352-9.

10. Lowder C. Dexamethasone Intravitreal Implant for Noninfectious Intermediate or Posterior Uveitis. Arch Ophthalmol. 2011:129(5):545

11. Meyer LM, Schönfeld C-L. Secondary Glaucoma After Intravitreal Dexamethasone $0.7 \mathrm{mg}$ Implant in Patients with Retinal Vein Occlusion: A One-Year Follow-Up. J Ocul Pharmacol Ther. 2013;29(6):560-5.

12. Malclès A, Dot $C$, Voirin N, Agard É, Vié A, Bellocq D, et al. Real-life study in diabetic macular edema treated with dexamethasone implant: The Reldex Study. Retina. 2016;1-8.

13. Schmitz K, Maier M, Clemens CR, Höhn F, Wachtlin J, Lehmann F, et al. Zuverlassigkeit und Sicherheit von intravitrealen Ozurdex-Injektionen: Die ZERO-Studie. Ophthalmologe. 2014;111(1):44-52.

14. Jiménez-Gómez B, González-Montpetit M, Fonollosa Calduch A, Orive Bañuelos A, Valsero Franco S. Efectos de ozurdex en la presión intraocular. Estudio en la práctica clínica. Arch Soc Esp Oftalmol. 2015;90(9): 421-5. 